\title{
ИНТЕНСИВНОСТЬ И ПРОДОЛЖИТЕЛЬНОСТЬ ДВИЖЕНИЯ ПЛАСТОВЫХ ВОД ИЗ МАЛОДЕБИТНЫХ КОЛЛЕКТОРОВ ТОЛБАЧАНСКОЙ СВИТЫ
}

\author{
А. М. Янников \\ Мирнинская ГРЭ АК «АЛРОСА» ПАО (республика Саха-Якутия)
}

Поступила в редакцию 9 ноября 2017 г.

\begin{abstract}
Аннотация: приведены данные по месторождению трубки «Интернациональная», представлена общая гидрогеологическая характеристика рассолов толбачанской свиты. Рассмотрены интенсивность и продолжительность движения высокоминерализованных пластовых вод в малодебитных, сложенных трещиноватыми доломитами, коллекторах толбачанской свиты. Получены результаты, свидетельствующие о зависимости излива высокоминерализованных пластовых вод от структурно-тектонических и литолого-фациальных особенностей водовмещаюючих массивов горных пород. Установлено, что изменчивая интенсивность притока воды по скважинам обусловлена особенностями структурой водосодержащих коллекторов толбачанской свиты, отличающейся крайне низкими параметрами проводимости и крайне малыми естественными запасами высоконапорных высокоминерализованных пластовых вод и рассолов.
\end{abstract}

Ключевые слова: Непско-Ботуобинская антеклиза, Мирнинский выступ, месторождение трубки «Интернациональная», толбачанская свита, малодебитные трещиноватые коллекторы, высокоминерализованные воды, насыщенные рассоль хлоридного кальциевого состава.

\section{THE INTENSITY AND DURATION THE MOVEMENT OF FORMATION WATERS FROM MARGINAL COLLECTORS TOLBACHINSKII SUITE}

\begin{abstract}
International", the General hydrogeological characteristics of brines tolbachinskii Suite. Considered the intensity and duration of the movement of highly mineralized formation water in marginal composed of fractured dolomite reservoirs tolbachinskii Suite. The results obtained indicate about the dependence of the spout of highly mineralized formation waters from a structural-tectonic and lithological-facial features of water-bearing rocks. It is established that the changing intensity of water inflow to wells due to the peculiarities of the structure of hydrous collectors tolbachinskii Suite with extremely low parameters of conductivity and extremely low stocks the natural high-pressure high-mineralized produced waters and brines.

Key words: Nepsko-Botuobinskaya antecline, Mirny ledge, field tubes "International", Tolbachinsky entourage, marginal fractured reservoirs, saline water, saturated brines of calcium chloride composition.
\end{abstract}

\section{Введение}

Трубка Интернациональная расположена в МалоБотуобинском алмазоносном районе, относящемся к Якутской алмазоносной провинции. Сама трубка приурочена к Кюелляхскому разлому и расположена в 0,4 км западнее его основной части [1]. До глубины 125 м она представляет собой воронкообразное, а на нижележащих горизонтах - практически цилиндрическое рудное тело с поперечным сечением овальной формы.

Месторождение приурочено к верховьям ручья Маччоба-Салаа - правого притока реки Ирелях [2], протекающей в 5,5 км севернее исследуемой трубки и являющейся правым притоком реки Малая Ботуобия, которая принадлежит бассейну р. Вилюй [3].
Краткая характеристика коренного месторождения алмазов трубка «Интернациональная»

Кимберлитовая трубка «Интернациональная» в доюрском эрозионном срезе имела форму неправильного овала, вытянутого в северо-западном направлении с размерами 152 м по длинной оси и 112 м - по короткой. Площадь поперечного сечения рудного тела составляла $12700 \mathrm{~m}^{2}$. В приповерхностной части (до глубины 70 м) рудное тело характеризовалось сравнительно пологими (до 45-70 ${ }^{\circ}$ к горизонту) контактами с вмещающими породами и представляло собой конусообразную форму [1]. Далее на глубину контакты приобретали более крутое падение, рудное тело постепенно приняло форму цилиндрического канала с почти вертикальными контактами. Морфология рудного тела в вертикальном разрезе напрямую 
зависит от литологического состава вмещающих пород. В пределах карбонатных пластов (уже при мощности 1,5-2,0 м) наблюдается сужение мощности рудного тела, а в пачках солей оно увеличивается в объеме за счет растворения солей газо-жидкостными флюидами кимберлитового расплава [4].

Трубка «Интернациональная» прорывает субгоризонтально залегающие галогенно-карбонатные и терригенно-карбонатные отложения нижнего палеозоя. С поверхности она была перекрыта маломощной (до 9,2 м) толщей нижнемезозойских отложений. Кимберлитовые породы состоят из псевдоморфоз серпентина и кальцита по оливину, единичных зерен пиропа, хромшпинелида и пикроильменита, сцементированных карбонат-серпентиновым агрегатом. Из ксенолитов распространены обломки карбонатных пород нижнего палеозоя (5-15\%, редко $30 \%$ ), в небольших количествах присутствуют траппы, обнаружены единичные обломки кристаллических сланцев фундамента сибирской платформы [1].

\section{Этапы отработки месторождения}

Месторождение отрабатывалось с 1971 года. Работы приостановлены в 1981 году на глубине 284 м в связи с достижением проектной глубины.

В 2005-2010 гг. проводилась повторная реконструкция карьера с увеличением глубины отработки до 315 м. Размеры карьера: по поверхности - 680×660 м, по дну $-115 \times 75$ м.

В 1999 году введен первый пусковой комплекс. Начата добыча руды подземным способом по слоям. Закладка выработанного пространства осуществлялась пустой породой[1].

В настоящее время отработка месторождения производится в интервалах отметок $(-690$ м $)-(-820$ м) с последующим увеличением до отм. $(-820$ м) - (1050 м). Данные интервалы сложены доломитами с прослоями известняков, ангидритов, каменных солей и мергелей толбачанской свиты нижнего кембрия.

\section{Краткая гидрогеологическая}

\section{характеристика толбачанской свить}

По результатам скважинной геофизики в отложениях толбачанской свиты выделяется 5 газонасыщенных коллекторов, 6 коллекторов газоводонасыщенных и 2 коллектора «сухих». Коллекторы состоят из пластов мощностью от 0,4 м до 4,5 м. Эффективная общая мощность газоводонасыщенных коллекторов толбачанской свиты составляет 91,4 м.

При откачке-отдувке компрессором ПКС-8/101 из толбачанского водоносного горизонта понижение уровня подземных вод составило 961,7 м. Дебит притока рассолов определен по скорости восстановления уровня в скважине и составил $0,037 \mathrm{~m}^{3} / 4$ ас $(0,88$ $\mathrm{M}^{3} /$ сут). Коэффициент водопроводимости горизонтов, определенный графоаналитическим методом, весьма низок и составил $0,36 \times 10^{-3} \mathrm{M}^{2} /$ сут.

Воды комплекса высоконапорные. По химическому составу рассолы комплекса хлоридного кальци- евого состава с минерализацией до 510 г/дм³ ${ }^{3}$ Они характеризуются кислой реакцией (рН до 5,8), очень высокими концентрациями брома, калия, стронция, лития, цинка, марганца

Формула солевого состава:

$$
M_{440-510} \frac{C l_{99}}{C a_{62}(\mathrm{Na}+\mathrm{K})_{22} M g_{16}} p h 5,8 \gamma 1,285
$$

Рассолы являются агрессивными к бетону и металлам по величине $\mathrm{pH}$ и содержанию магния.

В составе газов решающую роль играет метан (до $95 \%$ по объему), присутствуют тяжелые углеводороды [5].

\section{Производство работ по дегазации массива, выявление первичных закономерностей}

По причине наличия во вмещающих породах в приконтактовых зонах газовых скоплений на руднике ведётся бурение опережающих дегазационных скважин, целью которых является разгрузка горного массива от газов. Режимные наблюдения за данными скважинами проводились с 2013 года и продолжаются в настоящее время. Целью данных натурных наблюдений является контроль за параметрами горного массива, объёма выпущенного пластового газа и характером фиксируемых водопроявлений.

Изменчивая интенсивность притока воды по скважинам обусловлена особенностями водосодержащих коллекторов толбачанской свиты, отличающихся крайне низкими параметрами проводимости и крайне малыми естественными запасами высоконапорных высокоминерализованных (до 510 г/дм³ ${ }^{3}$ пластовых вод (рассолов). В ненарушенных условиях для скважин характерно непостоянство расходов (дебитов) наблюдаемых притоков воды и их невысокая дебитность (фиксируемые притоки не превышали 250-300 дм $^{3} /$ час). Самоизлив воды, как правило, был не продолжителен, эпизодичен. За фиксируемыми в ходе натурных наблюдений «всплесками активности», (продолжительностью от 2-3 до 10-14 дней) следовали долговременные периоды с полным отсутствием какого-либо излива воды. У каждой скважины, (из числа тех, на которых отмечалось наличие притоков пластовых вод), был сформирован свой режим, вероятно, обусловленный их расположением относительно участков сложного структурно-тектонического строения, приуроченных к низкоамплитудному тектоническому нарушению, которое фиксируется по наличию сближенных кимберлитовых жил, ступенчатых сбросов и флексурных перегибов слоёв вмещающих пород.

Отмечаемое изменение интенсивности притоков воды по всем скважинам подземных горных выработок в зависимости от времени года, связано с рядом факторов, одним из которых является колебание барометрического (атмосферного) давления. При сравнительном анализе наложенных графиков совместного прослеживания притоков воды отмечается несколько интервалов, характеризующих этапы форми- 
руемого режима самоизлива пластовых вод.

На первом этапе отмечается общая разгрузка вод пристволовой и призабойной зон скважин с приведённым радиусом влияния около 25 метров. Формирование данного радиуса напрямую зависит от вида и формы содержащегося флюида, как многокомпонентной системы (рассол + углеводородный газ + нефть + мальты) [6]. После разгрузки данных зон отмечается период стабилизации, во время которого по скважинам каких-либо притоков воды не отмечается.

Последующие этапы, связаны с фиксацией во время натурных наблюдений наличия или отсутствия самопроизвольного излива пластовых вод. При анализе данных этапов необходимо отметить достаточно чёткую корреляцию между интенсивностью и продолжительностью фиксируемых притоков воды и увеличением/уменьшением барометрического давления. Это в свою очередь, позволяет говорить, о зависимости скорости фильтрации пластовых рассолов из периферийных зон радиуса прямого и зон опосредованного влияния, от нагруженности горного массива массой атмосферного воздуха. Для установления достоверных корреляционных зависимостей этого процесса, в дальнейшем будет проведена более детальная и раздельная (по выделяемым блокам) оценка влияния колебания атмосферного давления на интенсивность и продолжительность фиксируемых водопроявлений по скважинам дегазационной сети рудника «Интернациональный», в отметках $(-790$ м $)-(-1050$ м).

\section{АК «АЛРОСА» ПАО, г. Мирный, республика Саха-Якутия}

Янников Алексей Михайлович, Старший гидрогеолог Ботуобинской ГРЭ, аспирант кафедры гидрогеологии, инженерной геологии и геоэкологии Воронежского государственного университета

E-mail: yannikov90@mail.ru

Тел.: + 7 914-825-98-85

\section{Выводы}

Произведённый анализ коррелируемой взаимосвязи изменения атмосферного давления и интенсивности самоизлива пластовых вод по режимной сети скважин рудника «Интернациональный» позволяет говорить о необходимости более тщательного и подробного изучения данного процесса, исходя из структурно-тектонических и литолого-фациальных особенностей каждой пристволовой и призабойной зон на скважинах. Это, в свою очередь, позволит более точно прогнозировать изменение излива пластовых вод во времени.

\section{ЛИТЕРАТУРЫ}

1. Колганов, В. Ф. Горно-геологические особенности коренных месторождений алмазов Якутии / В. Ф. Колганов, А. Н. Акишев, А. В. Дроздов // Мирный, 2013. - С.96-121.

2. Гидрогеология СССР. Том ХХ. Якутская АССР. - М.: Недра, 1970. - С.83-100.

3. Бодунов, Е. И. Геология, гидрогеология и геохимия нефти и газа южного склона Анабарской антеклизы / Е. И. Бодунов [и др.] // Якутск: изд. ЯФ СО АН СССР, 1986. - 176 с.

4. Зуева. И. Н. Химическая структура нафтидов ДалдыноАлакитского района. (По данным ИК- и УФ-спектроскопии). / И. Н. Зуева, Н. А. Уткина, Е. И. Бодунов // Якутск: Изд-во Якут. филиала СО АН СССР, 1987. - С. 99-110.

5. Крайча, Я. Газы в подземных водах / Я. Крайча // М.: Недра, 1990. - С.23-42.

6. Вассоевич, Н. Б. Природа органического вещества / Н. Б. Вассоевич [и др.] // М. : Наука, 1973. - С.51-70.

\section{AK "ALROSA" PAO, Mirny, Republic of Sakha-Yakutia}

Yannikov A. M., Senior hydrogeologist Botuobinskaya GRE, graduate of the hydrogeology, Engineering Geology and Geoecology Department of Voronezh State University

E-mail: yannikov90@mail.ru

Tel.: +7 914-825-98-85 